\title{
Predatory Mammal Species of Bitlis Province (Mammalia: Carnivora)
}

\author{
Kubilay TOYRAN ${ }^{1}$
}

ABSTRACT: Predatory mammals are a significant order located at the top of the food pyramid in the ecosystems in which they exist in the wild life. They have important roles in balancing the populations of animals which are smaller and large in numbers with a potential for spreading diseases and causing an economic loss. This study was based on field surveys conducted in the natural areas of Bitlis province between 2011 and 2015. It was determined in field surveys that Canis lupus, Vulpes vulpes, Ursus arctos, Mustela nivalis, Vormela peregusna, Martes foina, Meles meles, Lutra lutra, Felis silvestris, and Lynx lynx species from order Carnivora are distributed. Traffic accidents, habitat reduction and unconsciously hunting activities were observed as leading of the most important factors which threaten these species in the study field.

Keywords: Bitlis, carnivora, distribution

\section{Bitlis İli’nin Yırtıcı Memeli Türleri (Mammalia: Carnivora)}

ÖZET: Yırtıcı memeliler yaban hayatında bulundukları ekosistemlerdeki besin piramidinin en üst basamağında yer alan önemli bir takımdır. Hastalık yayma, ekonomik zarara yol açma potansiyeli olan daha küçük ve sayıca daha çok olan hayvanların populasyonlarının dengelenmesinde önemli rollere sahiptir. Bu çalışma 2011 ila 2015 yılları arasında Bitlis ili doğal alanlarında gerçekleştirilen arazi çalışmalarına dayanmaktadır. Yapılan arazi çalışmalarında Carnivora takımına ait Canis lupus, Vulpes vulpes, Ursus arctos, Mustela nivalis, Vormela peregusna, Martes foina, Meles meles, Lutra lutra, Felis silvestris ve Lynx lynx türlerinin yayılış gösterdiği saptanmıştır. Çalışma alanında bu türleri tehdit eden en önemli faktörlerin başında trafik kazaları, habitat daralması ile bilinçsiz şekilde yapılan avcılık faaliyetlerinin geldiği gözlenmiştir.

Anahtar Kelimeler: Bitlis, carnivora, yayılış

Bitlis Eren Üniversitesi, Fen Edebiyat Fakültesi, Biyoloji Bölümü, Bitlis, Türkiye

Sorumlu yazar/Corresponding Author: Kubilay TOYRAN, kubilaytoyran@hotmail.com 


\section{INTRODUCTION}

The order Carnivora is represented by 15 families, 126 genera, and 286 species around the world (Wilson and Reeder, 2005). 19 species from Canidae, Ursidae, Mustelidae, Viverridae, Hyaenidae, and Felidae families belonging to Carnivora are found in Turkey (Albayrak et al., 1997; Albayrak et al., 2008). The members of the order Carnivora are distributed in all continents and oceans except for the continent of Australia (Vaughan et al., 2000). The members of the order Carnivora live in all types of terrestrial and several aquatic habitats from poles to tropical zones (Stains, 1984; Vaughan et al., 2000).

The purpose of this study is to determine predatory mammals being distributed in Bitlis province, population conditions of the species, and some bioecological characteristics.

\section{MATERIAL AND METHODS}

This study was based on field surveys conducted in the natural areas of Bitlis province between 2011 and 2015. Photo-traps were set to areas appropriate for determination of species belonging to the order Carnivora. Some species have been recorded directly photographed. Existence of species were tried to be determined through foot prints, feces, skull, and fur residues. Members obtained as dead due to reasons such as traffic accidents were taxidermized. Knowledge of local people was consulted in order to get information about the presence of species. Biological and ecological notes of species determined were given. Data and photographs regarding species as well as their conservation status according to IUCN were recorded.

\section{RESULTS AND DISCUSSION}

Existence of totally 10 species such as Canis lupus, Vulpes vulpes, Ursus arctos, Mustela nivalis, Vormela peregusna, Martes foina, Meles meles, Lutra lutra, Felis silvestris, and Lynx lynx belonging to the order Carnivora from Bitlis province was determined as a result of study.

\section{Canis lupus Linnaeus, 1758 (Wolf)}

1758. Canis lupus Linnaeus, Systema Naturae, 10 th ed., 1:39

Type locality: Sweden

General Characteristics: It is found in steppe, moor, forestland, and highlands. Food choice is quite variable. It is generally fed with herbivorous mammals, and sometimes hunts small rodents and birds. It has a quite wide distribution in Turkey (Kaya et al., 2011). It was determined to be widespread in Bitlis province (Figure 1).

Conservation Status: IUCN - Least Concern (LC) (IUCN, 2016).

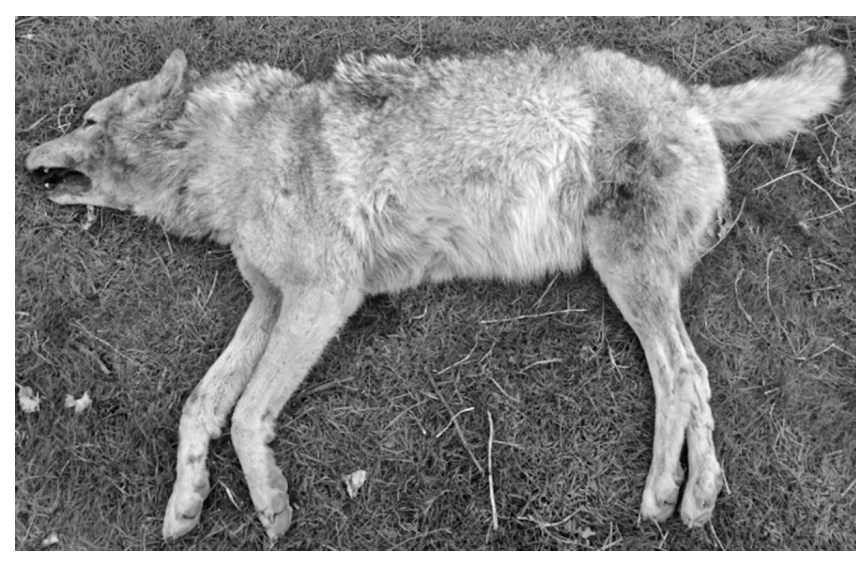

Figure 1. Canis lupus (Photograph: K. Toyran)

\section{Vulpes vulpes (Linnaeus, 1758) (Red Fox)}

1758. Canis vulpes Linnaeus, Systema Naturae, 10 th ed., 1:40.

Type locality: Sweden

1898. Vulpes vulpes Thomas, The Zoologist, 4th ser., II, p. 100.

General Characteristics: It is found in all kinds of habitats particularly in forestland and moor. Although it feeds on rabbits, small rodents, birds, insects, and other invertebrates, it also eats fruits such as grapes, apricot, and blackberry. It is found in all regions of Turkey (Kaya et al., 2011). It was determined to be prevalent in Bitlis province (Figure 2). 
Conservation Status: IUCN - Least Concern (LC) (IUCN, 2016).

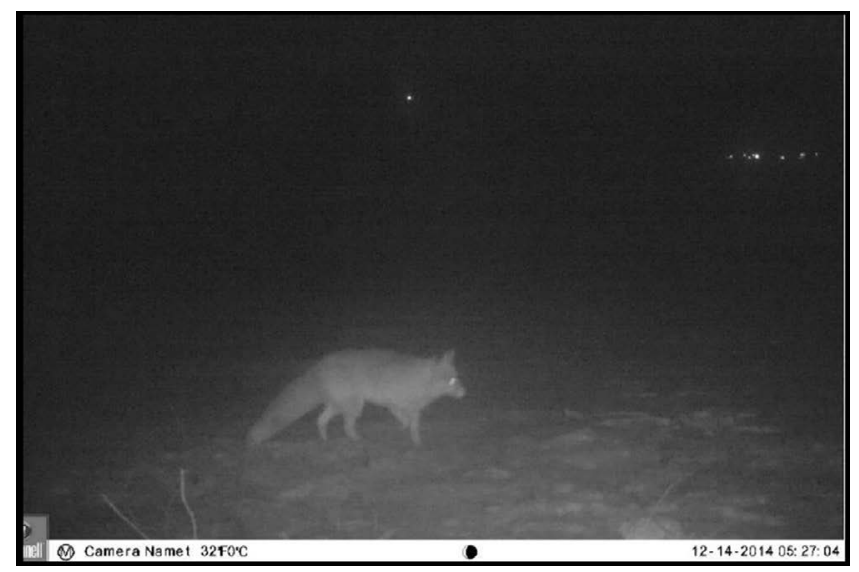

Figure 2. Vulpes vulpes (Photograph: K. Toyran)

\section{Ursus arctos Linnaeus, 1758 (Brown Bear)}

1758. Ursus arctos Linnaeus, Systema Naturae, 10th ed., 1: 47

Type locality: Upsala, Sweden

General Characteristics: It is found in moors, steep mountains, broad-leaved and mixed forests. Although its diet is quite variable, it feeds on large mammals, small mammals, bird eggs, larvae of insects, snails, wigglers, green parts of plants, grained fruits, and oil and starchy seeds. It is distributed in almost all regions of Turkey except for Thrace region (Demirsoy, 2003). It was determined in Güroymak, Buzlupınar site, and Natural Monument of Nemrut Caldera in Bitlis province (Figure 3).

Conservation Status: IUCN - Least Concern (LC) (IUCN, 2016).

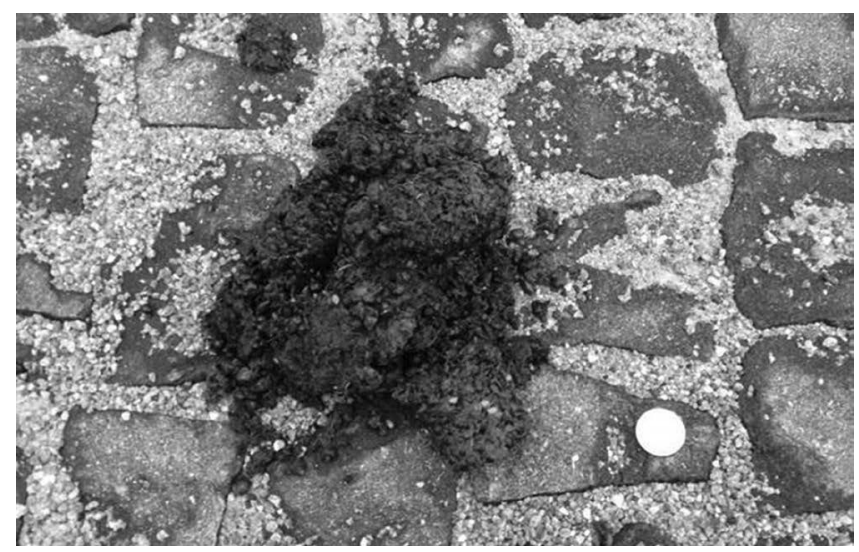

Figure 3. The feces of the Ursus arctos (Photograph: K. Toyran)

\section{Mustela nivalis Linnaeus, 1766 (Weasel)}

1766. [Mustela] nivalis Linnaeus, Syst. Nat., 12th ed., p. 69

Type locality: Sweden

General Characteristics: It appears in forestlands, steppes, and agricultural lands. It feeds on rodents, birds and bird eggs, and larger insects. It is distributed in all regions of Turkey (Kaya et al., 2011). It was determined in the campus site of Bitlis Eren University in Bitlis, and it is one of the rare species (Figure 4).

Conservation Status: IUCN - Least Concern (LC) (IUCN, 2016).

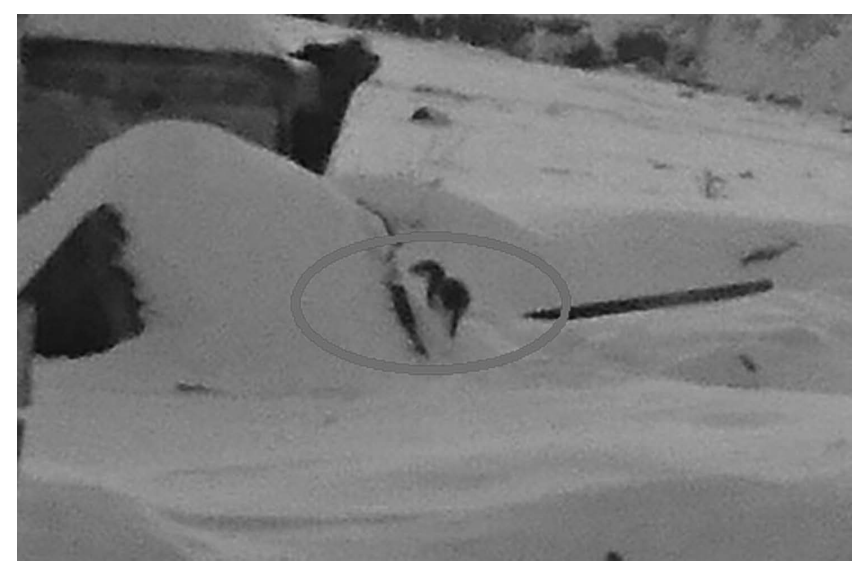

Figure 4. Mustela nivalis (Photograph: K. Toyran)

\section{Vormela peregusna (Güldenstädt, 1770) (Marbled Polecat)}

1770. Mustela peregusna Güldenstädt, Nova Comm. Imp. Acad. Sci. Petropoli, 14 (1): 441

Type locality: Russia

1910. Vormela peregusna Miller, Proceedings of the United States Nat. Mus., 38: 385.

General Characteristics: It is found in gardens, agricultural lands, semi arid areas, and waterfront areas close to residential areas. It feeds on rabbits, rodents, birds, reptiles, frogs, and insects. It has numerous records of distribution from many areas in Thrace, Black Sea, Central and Eastern Anatolia in Turkey (Demirsoy, 2003; Arslan and Zima, 2013). It was determined in Ahlat, Tatvan, and Natural Monument of Nemrut Caldera in Bitlis province (Figure 5).

Conservation Status: IUCN - Vulnerable (VU) (IUCN, 2016). 


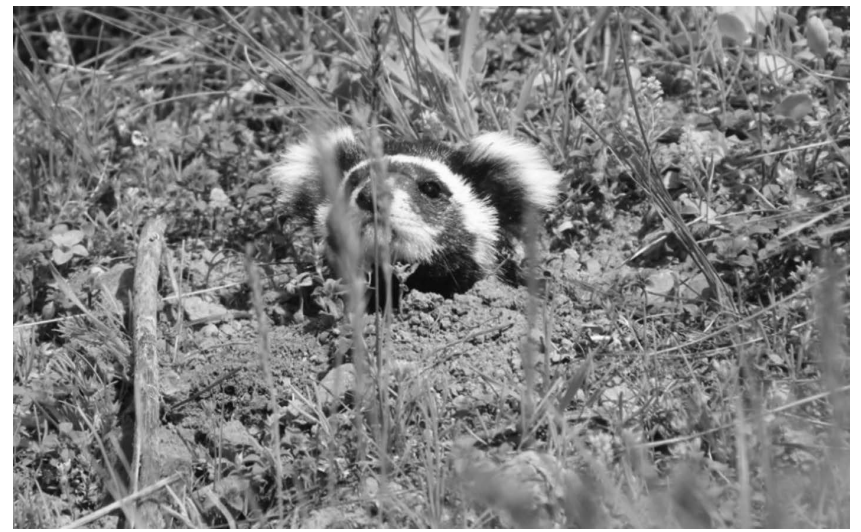

Figure 5. Vormela peregusna (Photograph: K. Toyran)

\section{Martes foina (Erxleben, 1777) (Beech Marten)}

1777. Mustela foina Erxleben, Sys. Regn. Anim. I:458

\section{Type locality: Germany}

1912. Martes foina Miller, Catalogue of Mammals of Western Europe, 365-381.

General Characteristics: It is found in rocky and stony areas, rough deciduous oak barrens. It feeds on rodents, birds and bird eggs, reptiles, and sometimes insects. Except for flat and wide plains, it appears in all regions in Turkey (Kaya et al., 2011). It was determined to be widespread in Bitlis province (Figure 6).

Conservation Status: IUCN - Least Concern (LC) (IUCN, 2016).

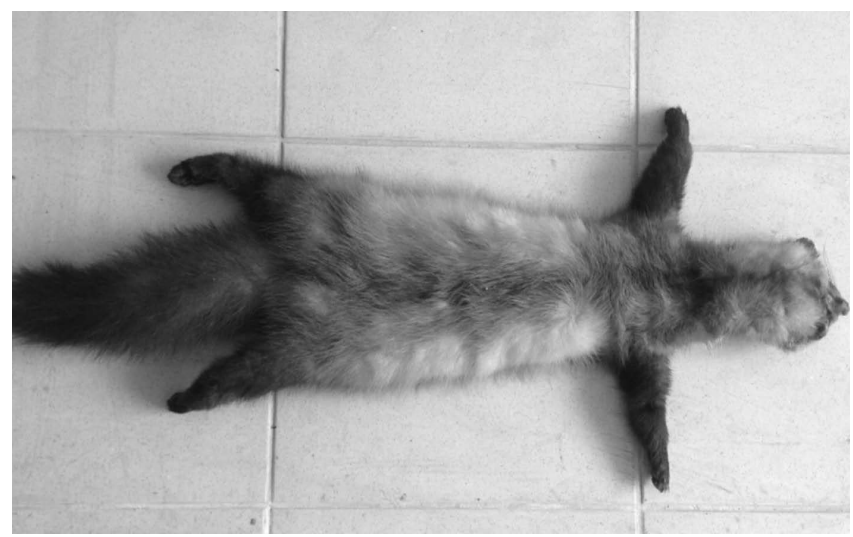

Figure 6. Martes foina (Photograph: K. Toyran)

\section{Meles meles (Linnaeus, 1758) (Badger)}

1758. Ursus meles Linnaeus, Systema Naturae, $10^{\text {th }}$ ed., $1: 48$

Type locality: Sweden

1894. Meles meles Dahl, Die Heimat IV. P. 125

General Characteristics: It is found in forestlands containing mixed and open meadows, steppes and semisteppes, and agricultural lands. It feeds on rodents, bird eggs, frogs, wigglers, larvae of insects, and molluses. It appears in all regions up to $2000 \mathrm{~m}$ altitude in Turkey (Kaya et al., 2011). It was determined in Buzlupınar site in Bitlis province (Figure 7).

Conservation Status: IUCN - Least Concern (LC) (IUCN, 2016).

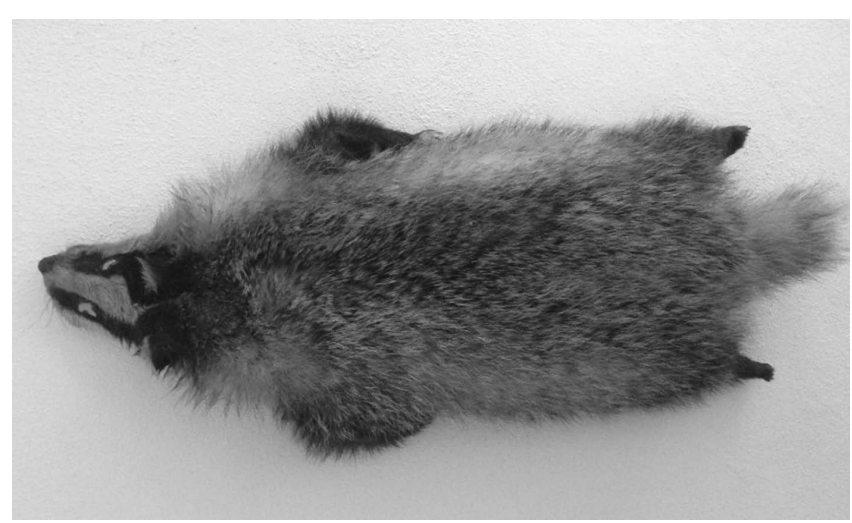

Figure 7. Meles meles (Photograph: K. Toyran)

\section{Lutra lutra (Linnaeus, 1758) (Otter)}

1758. [Mustela] lutra Linnaeus, Syst. Nat. Tomus I, 10 th ed., P.45.

Type locality: Upsala, Sweden

1910. Lutra lutra Trouessart, Fauna Mamm., d'Europe, p.86

General Characteristics: It is found in sheltered regions where vegetation is heavy in streams and brooks. It feeds on fish, small mammals, birds, and invertebrates like crabs. It is distributed in all regions of Turkey (Kaya et al., 2011). It was determined in Bitlis Stream, Güzeldere, and Sutopu Stream in Bitlis Province (Figure 8).

Conservation Status: IUCN - Near Threatened (NT) (IUCN, 2016). 


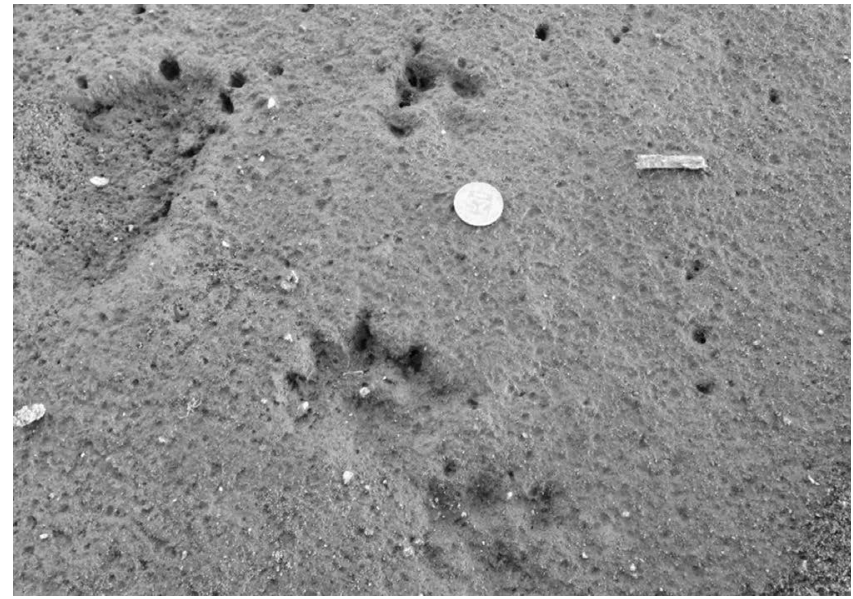

Figure 8. The foot prints of the Lutra lutra (Photograph: K. Toyran)

\section{Felis silvestris Schreber, 1777 (Wild Cat)}

1777. Felis silvestris Schreber, Die Säugethiere, 3 (23): 397

\section{Type locality: Germany}

General Characteristics: It is found in broad-leaved and mixed forests and shrubs close to residential areas. It feeds on rabbits and rodents. It is distributed almost in all regions of Turkey (Kaya et al., 2011). It was determined in Buzlupınar site in Bitlis province (Figure 9).

Conservation Status: IUCN - Least Concern (LC) (IUCN, 2016).

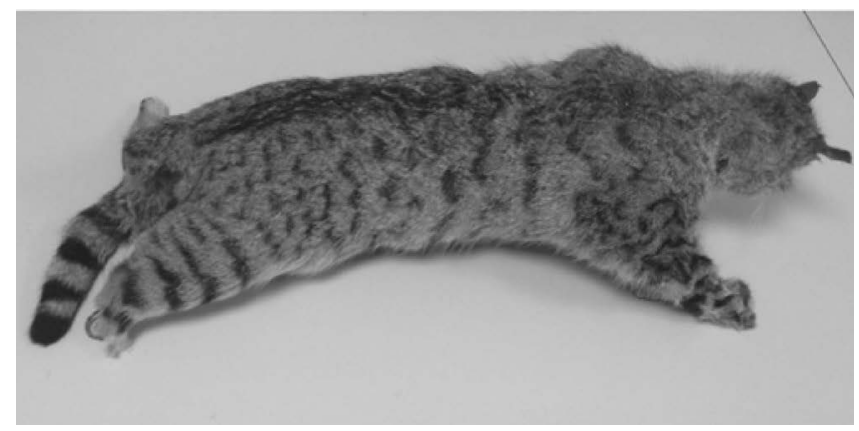

Figure 9. Felis silvestris (Photograph: K. Toyran)

\section{Lynx lynx (Linnaeus, 1758) (Eurasian Lynx)}

1758. Felis lynx Linnaeus, Systema Naturae, 10th ed., 1: 43

Type locality: Upsala, Sweden

General Characteristics: It is found in broad-leaved and mixed forestlands, and oak steep barrens. It feeds on rabbits, mountain goats, birds, and rodents.
Distribution records from Bursa, Balıkesir, Çanakkale, İzmir, Aydın, Denizli, Bolu, Ankara, Kastamonu, Zonguldak, Samsun, Ordu, Giresun, Trabzon, Artvin, Rize, Kars, Erzurum, Bingöl, Siirt, Hakkâri, Mersin, and Konya in Turkey are present (Kaya et al., 2011). It was determined in Buzlupınar site in Bitlis province (Figure 10).

Conservation Status: IUCN - Least Concern (LC) (IUCN, 2016).

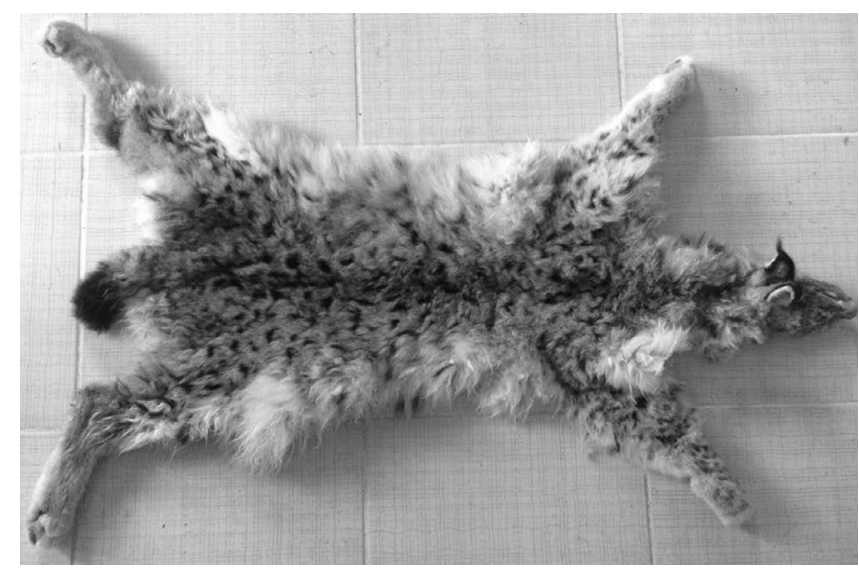

Figure 10. Lynx lynx (Photograph: K. Toyran)

Turkey, which shows continental characteristics due to its geographical position, has an important richness in terms of biodiversity. Almost 170 species from the class mammalia are present in Turkey. The order Carnivora constitutes a significant group of the class mammalia and totally 19 species which belong to Canidae, Ursidae, Mustelidae, Herpestidae, Hyaenidae, and Felidae families are distributed in Turkey (Albayrak et al., 1997; Albayrak et al., 2008).

A great majority of the order Carnivora members are under threat due to reasons such as hunting pressure, habitat reduction, and traffic accidents. Some parts are endangered and about to extinct. Species such as Anatolian leopard (Phantera pardus tulliana), otter (Lutra lutra), and pine marten (Martes martes), widely found in Turkey once upon a time, are examples of these. Population density of otters has reached a certain level through intense studies and raising the awareness of public. Destruction of forestlands adversely affected pine martens. It was found that while the most significant factor threatening otter from determined species which belongs to the order Carnivora in Bitlis province was habitat loss, hunting was observed as the biggest threat for wolf, fox, badger, lynx, wild cat, and beech marten. 
Additionally, it was determined that weasel and marbled polecat were rare species.

It was observed that 10 of 19 carnivore species found in Turkey were distributed in Bitlis province as they were evaluated in terms of the number of species. The fact that Bitlis province has relatively undisturbed nature, it has no industrialization, and it involves various habitats that is the biggest factor in formation of carnivore species diversity.

\section{REFERENCES}

Albayrak İ, Pamukoğlu N, Aşan N, 1997. Bibliography of Turkish Carnivores (Mammalia: Carnivore). Communication Fas. des. Scien. de L univ. d-Ankara. Series C, 15: 1-20.

Albayrak İ, Özen SA, Kitchener AC, 2008. A Contribution to AgeClass Determination of Martes foina Erxleben, 1777 from Turkey (Mammalia: Carnivora). Turk J Zool, 32 (2): 147-153.

Arslan A, Zima J, 2013. Distribution of C-heterochromatin and Nucleolar Organizer Regions in the Karyotype of Marbled Polecat (Vormela peregusna, Carnivora: Mustelidae). Acta Zoologica Bulgarica, 65 (4): 557-560.

Demirsoy A, 2003. Türkiye Omurgalıları (Memeliler). Meteksan A.Ş., Ankara. 292 p.

IUCN, 2016. IUCN Red List. http://www.iucnredlist.org (Erişim tarihi: 04 Ocak, 2016).

Kaya A, Tel AZ, Avcı A, Ilgaz Ç, Özuslu E, Yağmur EA, İzler F, Koç H, Toprak HHC, Sevgili H, Toyran K, Öztekin M, Kırmacı M, Üzüm N, Kaya R, Sungur Birecikligil S, Bozacı V, 2011. Memeli Hayvanlar (Mammalia). 483-524, İçinde: Gaziantep'in Biyolojik Çeşitliliği (Özuslu, E., Tel, A.Z., eds), Doğa Koruma Derneği Yayınları, Gaziantep. 568 p.

Stains H, 1984. Carnivores. Orders and Families of Recent Mammals of the World. 491-521. Ed: S. Anderson and J. K. Jones Jr., John Wiley and Sons. New York. 686 p.

Vaughan T, Ryan J, Czaplewski N, 2000. Mammalogy, 4th Edition. Toronto: Brooks Cole. 565 p.

Wilson DE, Reeder DM, 2005. Mammal Species of the World. A Taxonomic and Geographic Reference. 3rd ed. Johns Hopkins University Press, Baltimore. 2000 p. 